\title{
Anmeldelse: Nedrustnings- begrebets lange vej gennem folkeretten
}

\author{
Af Henrik Døcker
}

Dansk diplomat belyser de internationale nedrustningsbestræbelser i både et historisk og folkeretligt perspektiv - helt tilbage til de første forsøg på at etablere en international verdensorden baseret på fredelig konfliktløsning.

John Kierulf: Disarmament under international Law, DJØF Forlag, 276 sider.

Bestræbelser på globalt at begrænse rustningerne har ikke siden 1990'erne haft nogen fremtrædende plads i international sikkerhedspolitik, og forhandlinger om reduktion af atomvåbnene er gået i stå. Alligevel er det vigtigt, at der udgives en bog som John Kierulfs, der i sin engelske udgave er en à jour-føring af den dansksprogede Nedrustning i et folkeretligt perspektiv, der udkom i 2014. Som jurist og dansk diplomat har Kierulf i årevis beskæftiget sig med emnet, der her udfoldes i mange detaljer, men på en overskuelig måde.

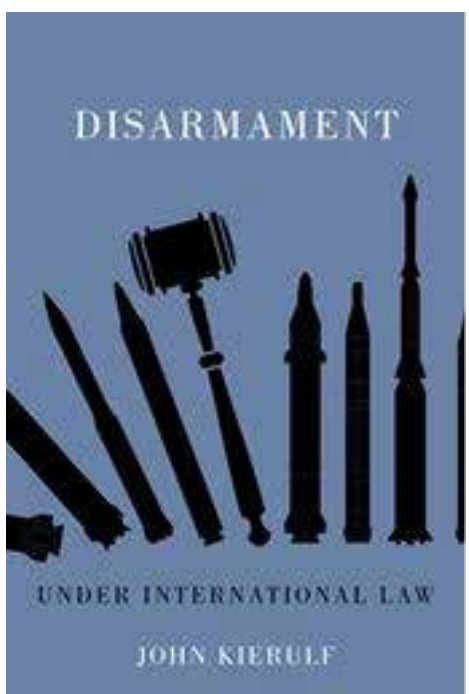

Kontrol med våben og forsøg på at reducere dem - eller rettere de farligste af dem - har været udfoldet i de sidste godt 100 år. Men det var først efter Anden Verdenskrig, at der kom rigtig skub i dem under indtryk af atombombesprængningerne over Hiroshima og Nagasaki. Med Kierulf international politik og ret i dansk dags- og tidskriftpresse. 
skal vi dog have forhistorien med. På en måde tog den moderne, eller, om man vil, nutidens folkeret sin begyndelse i 1899, da der på initiativ af Rusland indkaldtes til en såkaldt fredskonference i Haag med det formål at sikre freden gennem begrænsning af større våbenlagre, som datidens stormagter, særlig Tyskland, opbyggede. Her blev brug af dumdum-kugler og giftige gasser bl.a. forbudt.

På en anden Haag-fredskonference i 1907 vedtoges en række konventioner om krigsførelse, herunder det, der på dansk blev kendt som Haag-landkrigsreglementet. Heraf fremgik bl.a., at krigsførende (stater) ikke havde ubegrænset ret til at skade fjenden, idet gift eller forgiftede gasarter og brug af projektiler eller våben, som forårsagede unødvendige lidelser, blev forbudt.

Alt dette og meget mere kom til at indgå i de Geneve-konventioner, der i Røde Kors-regi kom til verden i 1949. Haag-konferencerne støbte så at sige fundamentet til det, der efter Anden Verdenskrig blev udviklet som den humanitære folkeret, et moderne udtryk for krigens folkeret.

Afbrudt af Første Verdenskrig kom nedrustningsforsøg først videre i Folkeforbundets regi, og da især i form af straffeforanstaltninger til krigens store tabermagt Tyskland. Begrænsninger, som dette land efter nazisternes magtovertagelse i 1933 lod hånt om, og som omverdenen trods Versailles-traktatens bestemmelser ikke greb ind overfor. Forinden lykkedes det internationalt gennem en såkaldt Geneve-protokol af 1925 at få forbudt kvælende, giftige gasarter og bakteriologiske krigsmidler, foranlediget af smertelige menneskelige tab og lidelser under verdenskrigen.

På det storpolitiske plan tiltrådte Frankrig, Tyskland og USA i 1929 den såkaldte Briand-Kelogg-pagt (opkaldt efter hen- holdsvis den franske og amerikanske udenrigsminister), der forsagede krig som sådan - et forsøg, der angiveligt (men det nævner Kierulff ikke) var ansporet af de europæiske magter for at få USA med i et slags sikkerhedssystem, eftersom amerikanerne ikke var blevet medlem af Folkeforbundet.

\section{Første anti-atomtraktat i FN-regi}

Med Kierulff ved hånden kan man notere sig, at Folkeforbundet i 1932 indkaldte til verdens første internationale nedrustningskonference, som imidlertid led skibbrud, da Tyskland forlod den - og siden også Folkeforbundet. Masseødelæggelsesvåben blev betegnelsen for ikke-konventionelle våben, der forårsager store, ukontrollable tab og ødelæggelser, første gang brugt af den spanske oprørsgeneral Francisco Francos tropper mod den baskiske by Guernica i den spanske borgerkrig i 1937.

I dag regnes atomvåben foruden biologiske og kemiske våben samt disses fremføringsmidler (missiler) for masseødelæggende. Ifølge bogen findes der i dag - spredt på ni lande - i alt 17.270 atomvåben i verden. Yderligere 30 lande formodes at have teknologisk kapacitet til at udvikle og fremstille atomvåben.

I FN's pagt nævnes ordene nedrustning og våbenkontrol kun i tre af dens i alt 111 artikler, men ved den første resolution, som FN's Generalforsamling vedtog i januar 1946, nedsattes en atomenergikommission.

Forfatteren minder om, at den danske atomfysiker Niels Bohr, der deltog i det store amerikanske Manhattan-projekt, som udviklede atombomben, $i$ et åbent brev til FN af 9. januar 1950 påpegede den fare, atomenergien frembød, hvis den blev brugt til militære formål. (Det kan tilføjes, at ordet menneskerettigheder også kun fore- 
kommer tre steder i FN's pagt. Antallet af emner og begreber, som stater og pressionsgrupper har ivret for medtagelse i pagten, har givetvis været overvældende. Anmelderens bemærkning).

Den vigtigste globale aftale til begrænsning af atomvåbnene er uden for enhver tvivl anti-atomspredningstraktaten af 1 . juli 1968, som trådte i kraft to år efter. Den er i dag tiltrådt af 191 stater, dvs. hele verden undtagen Indien, Israel og Pakistan foruden den unge stat Sydsudan. Nordkorea var oprindelig også bundet af traktaten, men i 1993 opsagde det den.

Der skelnes imidlertid mellem de (i forvejen) atomvåben-besiddende stater og så de, der ikke har disse våben. I førstnævnte kategori er Frankrig, Kina, Rusland, Storbritannien og USA - de er (tilfældigvis?) også permanente medlemmer af FN's sikkerhedsråd.

Forfatteren føjer til, at de teknologiske fremskridt har gjort det muligt at sikre atomvåbnenes fortsatte funktionsdygtighed uden at foretage atomprøvesprængninger. Ved computersimulation kan der endog udvikles nye former for atomvåben og afprøvning af dem - og ja, så kunne atomstaterne jo lige så godt tiltræde den traktat med forbud mod atomprøvesprængninger, som FN's Generalforsamling vedtog i 2015. 164 har allerede ratificeret den - et udtryk for at dette emne er godt på vej til at blive del af international sædvaneret, bemærker Kierulf.

\section{Fem tilfælde af atomkrigsfare}

Efter bogens udgivelse lykkedes det i sommeren 2017 på en FN-konference at få vedtaget verdens første atomforbudstraktat, som kun retter sig til de stater, der ikke i forvejen har atomvåben; de lover at afstå fra at afprøve, fremstille, erhverve, besidde eller oplagre atomvåben. Trakta- ten træder i kraft, når 50 stater har ratificeret den.

Kierulf har dog omhyggelig redegjort for traktaten i sin bog, hvoraf det fremgår, at den definerer 'atomsikkerhed' som dette, at staterne i forbindelse med atomvåben forebygger og afslører tyveri af dem, deres brug til sabotage, ulovlige eller andre ondsindede handlinger. Man fristes til at sige, at papiret er tålmodigt, og at løfterne er mange - uden at udsigten til den store 'bremseværdi' er særlig let at få øje på. Kierulf finder imidlertid, at konventionen udfylder farlige mangler i det, som han kalder 'det nuværende atomregime', idet den kan medvirke til at forebygge atomterrorisme.

Forfatteren gør opmærksom på, at verden har været tæt på atomkrig mindst fem gange siden atomvåbnenes fremkomst:

(1) Ved Cuba-krisen i 1962, da kaptajnen på en atombevæbnet sovjetisk ubåd var på nippet til at affyre en atomtorpedo, men blev bremset af sin overordnede, kommandøren for den del af sovjetflåden, som befandt sig i farvandet omkring Cuba.

(2) Da det ved en computerfejl i en amerikansk kommandocentral - som heldigvis blev opdaget - i 1980 blev meldt, at et sovjetisk atomangreb var blevet iværksat.

(3) Da en sovjetisk officer i et missil-kontrolcenter i 1983 modtog signal om, at et amerikansk missilangreb var blevet iværksat, men valgte at afstå fra et gengældelsesangreb i sidste øjeblik.

(4) Da NATO mindre end to måneder senere gennemførte en større øvelse, som Sovjetunionens politiske og militære ledelse først troede var indledningen til et atomangreb.

(5) Da en amerikansk raket med forskningsformål blev affyret fra en norsk ø nær den sovjetiske kyst. Selv om russerne var blevet adviseret, så var meldingen ikke nået frem til Sovjetsunionens såkaldte 'ear- 
ly warning'- system, men en reaktion herpå blev så også her afværget i sidste sekund.

Under gennemgang af atomfrie zoner i verden konstaterer forfatteren, at en sådan ikke har kunnet oprettes i Mellemøsten på grund af Israels de facto-besiddelse af atomvåben. Nok er Norden også (de facto) en atomfri zone, men formelt skal den ikke være det, idet en sådan status, som forfatteren ser det, ville have fjernet fleksibilitet $\mathrm{i}$ den sikkerhedspolitiske handlefrihed, som Danmark siden 1957 har nydt godt af.

Fravær af denne ville have udelukket os fra at blive forsvaret med atomvåben af andre nationer. $O g$ sådan frembyder bogen i det hele taget noget nær en guldgrube af viden om biologiske, kemiske og radiologiske våben, håndvåben, lette våben, antipersonelminer og klyngebomber med meget mere. Om droner, der også kaldes 'ubemandede luftfartøjer', oplyses det, at der i dag findes 50 forskellige typer, som produceres i 50 forskellige lande.

\section{Mistillid og kontrolvanskeligheder}

Hvis nogen skulle have haft opfattelsen af, at NATOs forhold til Rusland inden den nuværende Ukraine/Krim-krise var bare nogenlunde tilfredsstillende, kan de hos Kierulf hente stof til eftertanke.

Siden 2007 har Rusland således ikke udvekslet oplysninger om antal, placeringer og flytninger af konventionelle våben og udstyr, således som ellers forudsat i traktaten om konventionelle væbnede styrker i Europa (CFE). Det er blevet begrundet med, at NATO-landene ikke har ratificeret en tilpasningsaftale under CFE, hvad disse magter igen begrundede med manglende russisk troppetilbagetrækning fra Moldova (nærmere bestemt udbryderrepublikken Transnistrien) og styrkereduk- tioner i Georgien. Som forfatteren anfører, er Ruslands suspension folkeretsstridig, da CFE-traktaten ikke åbner mulighed for en sådan undtagelse.

Det er umuligt blot tilnærmelsesvis at komme ind på alle de emner, som bogen indeholder: Våbenhandel, eksportkontrol, brug af de internationale domstole, minerydning og meget andet. Kierulf minder om et Lenin-citat, som USA's tidligere præsident Ronald Reagan yndede, og som på engelsk lyder 'Trust but verify'. (Den danske version lyder almindeligvis 'Tillid er godt, kontrol er bedre').

Essensen er, at alle disse rustningstraktater (som andre internationale aftaler) bør kontrolleres, det vil sige efterprøves, for så vidt angår deres efterlevelse. I diplomatfagsproget: Verificeres. Man taler også om at monitorere. Og, ja, der er masser af problemer med dette, måske tydeligst eksemplificeret ved de vanskeligheder inspektører fra IAEA (Det Internationale Atomenergiagentur) har mødt og har været konfronteret med i Iran. Tidligere var det Irak under Saddam Hussein.

I den store informationsmængde serveres læseren også for overskuelige facts om Danmarks nedrustningspolitik, herunder indsatsen for at begrænse spredningen af atomvåben. Et oversigtsværk, holdt i mundret sprog, som på det varmeste må anbefales alle med interesse for ét af FN's nøgleområder: nedrustningsbestræbelserne.

Denne bog har ud over sine mange detaljeoplysninger om atomvåben som sådan og særlig de traktater og andre internationale vedtagelser om dem også en række nyttige personlige kommentarer efter hvert af de 14 kapitler. De styrker læserens refleksion over de mange informationer. 